Article

\title{
Reduction Process of Iron Catalyst Precursors for Ammonia Synthesis Doped with Lithium Oxide
}

\author{
Roman Jedrzejewski ${ }^{1}\left(\mathbb{D}\right.$ and Zofia Lendzion-Bielun ${ }^{2, *}$ (D) \\ 1 Institute of Materials Science and Engineering, West Pomeranian University of Technology, Szczecin, \\ al. Piastów 19, 70-310 Szczecin, Poland; roman.jedrzejewski@zut.edu.pl \\ 2 Institute of Inorganic Chemical Technology and Environment Engineering, Faculty of Chemical Technology \\ and Engineering, West Pomeranian University of Technology, Szczecin, ul. Pułaskiego 10, \\ 70-322 Szczecin, Poland \\ * Correspondence: zosi@zut.edu.pl
}

Received: 20 September 2018; Accepted: 16 October 2018; Published: 25 October 2018

check for updates

\begin{abstract}
Iron catalyst precursors promoted with oxides of calcium, aluminum, and lithium were prepared by a fusion method. Using XRD analysis, it was found that catalyst precursors had a magnetite structure. Lithium oxide, which is dependent on the $\mathrm{Fe}^{2+} / \mathrm{Fe}^{3+}$ molar ratio in a catalyst, was built into the magnetite structure as a solid solution and/or formed a separate $\mathrm{Li}_{2} \mathrm{Fe}_{3} \mathrm{O}_{4}$ phase. Lithium oxide forming the solid solution in magnetite accelerated the magnetite phase reduction. However, it was observed that magnetite, in the presence of lithium oxide, was not reduced to iron directly, but to a transient phase, $\mathrm{Li}_{2} \mathrm{O} \cdot x \mathrm{FeO}$, where $\mathrm{x}<3$ was formed, which meant that the reduction to iron was much slower. Activity of the catalysts promoted with lithium oxide increased, while the degree of reduction increased.
\end{abstract}

Keywords: iron catalyst; ammonia synthesis; lithium oxide; reduction

\section{Introduction}

Iron catalyst is used in industrial processes of ammonia synthesis. The discovery of the iron-fused catalyst for the synthesis of ammonia has created the foundations for our current understanding of heterogeneous catalysis [1-5]. Today, iron-based catalysts are tested in hydrogen gas processes e.g., water gas shift reaction and ammonia decomposition [6-10]. Due to huge energy consumption in the process of ammonia synthesis, research into the creation of a new catalyst that enables running the synthesis at lower temperatures and pressures is still required.

On the basis of previous results it can be concluded that iron is the most effective catalyst in the ammonia synthesis among elements.

An iron catalyst precursor is obtained by melting magnetite and promoters. An oxidized form of the magnetite-based catalyst is composed mainly of iron oxide $\mathrm{Fe}_{3} \mathrm{O}_{4}$; other metal oxides play the role of promoters. Oxides of aluminum, calcium, and potassium $\left(\mathrm{Al}_{2} \mathrm{O}_{3}, \mathrm{CaO}\right.$, and $\left.\mathrm{K}_{2} \mathrm{O}\right)$ are most frequently used. Oxides of aluminum and calcium are structure-building promoters, and they influence the catalyst structure, its specific surface area, and thermal resistance under reaction conditions [11-14]. Potassium oxide is an activating promoter that changes iron sorption properties by the modification of iron surface. The nature of the potassium-activating role is not unambiguously clarified. According to Ertl $[15,16]$, lattice planes, differing in Miller indices, showed differences in dissociative nitrogen chemisorption. The addition of potassium on the iron surface caused an equalization of activities of various lattice planes and, at the same time, made the activities much higher. Another mechanism has been proposed by Samorjai $[17,18]$. According to Samorjai, the presence of potassium eased desorption of the ammonia adsorbed on the catalyst surface and, as a result, more active sites were available. 
Moreover, the presence of potassium had a positive impact on the catalyst resistance to sulphur poisoning. On the other hand, the presence of potassium made the catalyst more sensitive to poisoning by oxygen compounds [19]. Potassium influence on catalyst structure and activity was similar when potassium was added into magnetite during a fusion process, as well as by an impregnation of a pre-reduced catalyst $[20,21]$.

Other alkali metals may have also had a positive impact on iron catalyst properties. It was found that cesium and rubidium activated a catalyst surface to a similar degree as potassium and, additionally, increased the thermal strength of the catalyst [22,23]. Lithium oxide, when added by impregnation, may be an effective promoter of an iron catalyst [24]. However, different results were obtained by Aleksicz [25]. Studying co-precipitated iron catalysts at atmospheric, as well as elevated, pressure (10 MPa) Aleksicz found that their activities decreased while the atomic number of alkali metals, used as a promoter, diminished. He proved that lithium was the worst promoter of iron catalysts. Bosch [26] examined the impact of alkali metals on the activity of co-precipitated iron catalysts promoted with $\mathrm{Al}_{2} \mathrm{O}_{3}$ and prepared by impregnating the solutions of carbonates and hydroxides. Aleksicz highlighted that the activity of the catalysts diminished while a ratio charge/alkali metal atom radius increased. If Aleksicz's results are to be taken as a rule, lithium should be a better activator than potassium. Interesting results were presented by the authors of another study [27], who found that the presence of $\mathrm{LiH}$ on the surface of the catalyst beside a transition metal, iron, made the second active site for nitrogen hydrogenation. Their results showed that the presence of $\mathrm{LiH}$ enabled the ammonium synthesis under milder conditions.

Differences in an appraisal of the lithium oxide activity probably arise due to the way in which it is added into catalysts, and as a consequence its location in an oxidized form of the catalyst.

An active form of the iron catalyst is obtained by an iron catalyst precursor reduction in a hydrogen or hydrogen-nitrogen atmosphere. The reduction and its parameters are crucially important when considering catalyst physicochemical properties [28]: namely, specific area and active surface area that have an influence on a total catalyst activity. The reduction of pure magnetite runs according to the shrinking core mechanism [29-32]. Hydrogen molecules diffuse through macropores in a grain of a precursor, and therefore, the reduction can also run inside the grain, after which a microcrystalline layer of iron is formed. The difference in lattice constants between iron and iron oxide causes micro stresses of crystals. The crystals reduce their size during the following reduction. Structure-building promoters are released from the precursor grain and they migrate to boundaries of the iron microcrystals preventing the crystals from sintering.

The aim of the current work was to examine the reduction process of fused iron catalyst precursors promoted with lithium oxide, in an attempt to provide clarification regarding the role of lithium oxide when introduced into catalyst precursors during a fusing process, and the lithium oxide location impact on the reduction process, and the activity in ammonia synthesis.

\section{Results and Discussion}

Two catalyst precursors promoted with oxides of calcium, aluminum, and lithium were prepared by a fusion method. Chemical composition and molar ratio $\mathrm{Fe}^{2+} / \mathrm{Fe}^{3+}$ of the prepared precursors are given in (Table 1). A characteristic of the industrial iron catalyst (PS-3-INS Grupa Azoty) for the ammonia synthesis promoted with potassium oxide, marked as $\mathrm{KAT}-\mathrm{K}_{2} \mathrm{O}$, was also given in Table 1 . That catalyst was used as a reference point.

Table 1. Chemical composition and molar ratio $\left(\mathrm{R}=\mathrm{Fe}^{2+} / \mathrm{Fe}^{3+}\right)$ of the catalyst precursors.

\begin{tabular}{cccccc}
\hline \multirow{2}{*}{ Catalyst Precursor Name } & \multicolumn{4}{c}{ Content of Promoters [\%] } & \multirow{2}{*}{$\mathbf{R}=\mathbf{F e}^{2+} / \mathbf{F e}^{3+}$} \\
\cline { 2 - 5 } & $\mathbf{A l}_{2} \mathbf{O}_{\mathbf{3}}$ & $\mathbf{C a O}$ & $\mathbf{K}_{\mathbf{2}} \mathbf{O}$ & $\mathbf{L i}_{\mathbf{2}} \mathbf{O}$ & \\
\hline $\mathrm{KAT}-\mathrm{K}_{2} \mathrm{O}$ & 2.30 & 2.94 & 0.53 & - & 0.65 \\
$\mathrm{KAT} 1-\mathrm{Li}_{2} \mathrm{O}$ & 3.76 & 1.50 & - & 1.66 & 0.68 \\
$\mathrm{KAT} 2-\mathrm{Li}_{2} \mathrm{O}$ & 3.40 & 1.90 & - & 1.68 & 0.54 \\
\hline
\end{tabular}


Contents of calcium, aluminum, and lithium oxides were similar in the prepared lithium catalysts. However, these catalysts differed in molar ratio R. X-ray patterns of the obtained precursors are presented in (Figure 1).

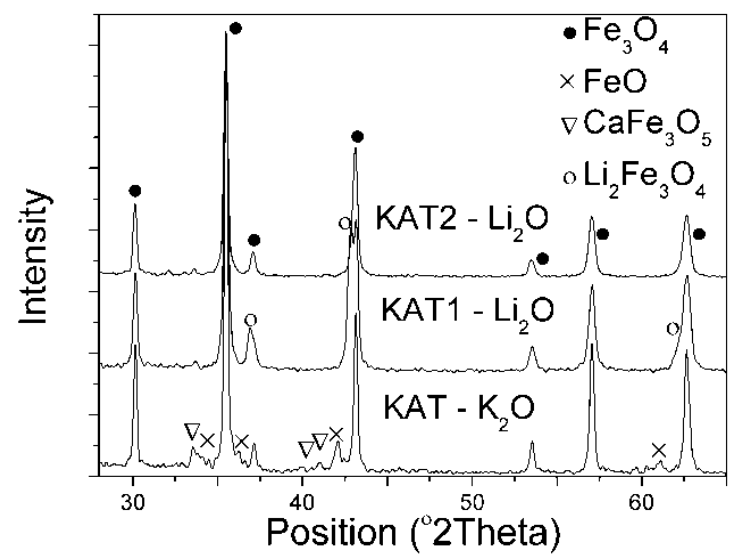

Figure 1. X-ray patterns of $\mathrm{KAT}-\mathrm{K}_{2} \mathrm{O}, \mathrm{KAT} 1-\mathrm{Li}_{2} \mathrm{O}$, and $\mathrm{KAT} 2-\mathrm{Li}_{2} \mathrm{O}$ catalyst precursors.

$\mathrm{Fe}_{3} \mathrm{O}_{4}, \mathrm{FeO}$, and $\mathrm{CaFe}_{3} \mathrm{O}_{5}$ phases were identified in the catalyst precursor $\mathrm{KAT}-\mathrm{K}_{2} \mathrm{O}$ promoted with potassium oxide. In the catalyst precursor $\mathrm{KAT} 1-\mathrm{Li}_{2} \mathrm{O}$, in that $\mathrm{Li}_{2} \mathrm{O}$ was an activating promoter and $\mathrm{R}=0.68$, the $\mathrm{FeO}$ phase did not occur in spite of an excess of $\mathrm{Fe}^{2+}$ ions in comparison to magnetite. The $\mathrm{CaFe}_{3} \mathrm{O}_{5}$ phase was not visible either. Peaks of magnetite and $\mathrm{Li}_{2} \mathrm{Fe}_{3} \mathrm{O}_{4}$ phases (according to ICDD: 37-1432 card) were identified. Both $\mathrm{Li}_{2} \mathrm{Fe}_{3} \mathrm{O}_{4}$ and $\mathrm{Fe}_{3} \mathrm{O}_{4}$ crystallized similarly in a cubic crystal system with the same space group, $\mathrm{Fd}-3 \mathrm{~m}$, and space group number 227. In the X-ray pattern of KAT2- $\mathrm{Li}_{2} \mathrm{O}$ catalyst, there were peaks belonging tomagnetite. No other peaks were observed in that precursor.

Authors of the previous work [33] found that potassium oxide in the iron magnetite-structure catalyst precursor was completely located within grain boundaries and not bound with iron oxides. The distribution of structural promoters $\left(\mathrm{CaO}, \mathrm{Al}_{2} \mathrm{O}_{3}\right)$ in an iron catalyst precursor depended on the molar ratio of iron ions $\mathrm{R}$ [34]. The distribution of promoters in the structure of an iron catalyst promoted with $\mathrm{Li}_{2} \mathrm{O}$ was presented in the paper [35]. The authors concluded that lithium oxide was bound with iron oxides and formed a separate $\mathrm{Li}_{2} \mathrm{Fe}_{3} \mathrm{O}_{4}$ phase.

On the basis of the $\mathrm{X}$-ray diffraction, it was stated that lithium oxide in the iron catalyst precursor may have occurred as the separate phase $\mathrm{Li}_{2} \mathrm{Fe}_{3} \mathrm{O}_{4}\left(\mathrm{KAT} 1-\mathrm{Li}_{2} \mathrm{O}\right)$ or formed the solid solution in magnetite (KAT2- $\mathrm{Li}_{2} \mathrm{O}$ ). Using the selective etching [35] it was found thatlithium oxide in the catalyst $\mathrm{KAT} 1-\mathrm{Li}_{2} \mathrm{O}$ in the amount of $14 \%$ formed the solid solution with magnetite while the rest formed the $\mathrm{Li}_{2} \mathrm{Fe}_{3} \mathrm{O}_{4}$ phase.

The reduction process of catalyst precursors in a hydrogen atmosphere was examined in a differential reactor with a thermogravimetric measurement device. The dependence of mass change on the precursor reduction time is shown in (Figure 2).

The reduction was carried out according to the procedure: polythermal heating from $25^{\circ} \mathrm{C}$ to $420{ }^{\circ} \mathrm{C}$ at a heating rate of $10{ }^{\circ} \mathrm{C} / \mathrm{min}$, next the isothermal reduction at a temperature of $420{ }^{\circ} \mathrm{C}$ until a sample mass was constant, polythermal heating from $420^{\circ} \mathrm{C}$ to $470{ }^{\circ} \mathrm{C}$ at a heating rate of $3.5^{\circ} \mathrm{C} / \mathrm{min}$, and the isothermal reduction at $470{ }^{\circ} \mathrm{C}$. The reduction was not completed at any case. The aim of the procedure was to determine the reduction run at the initial stage for catalysts of different phase contents. 


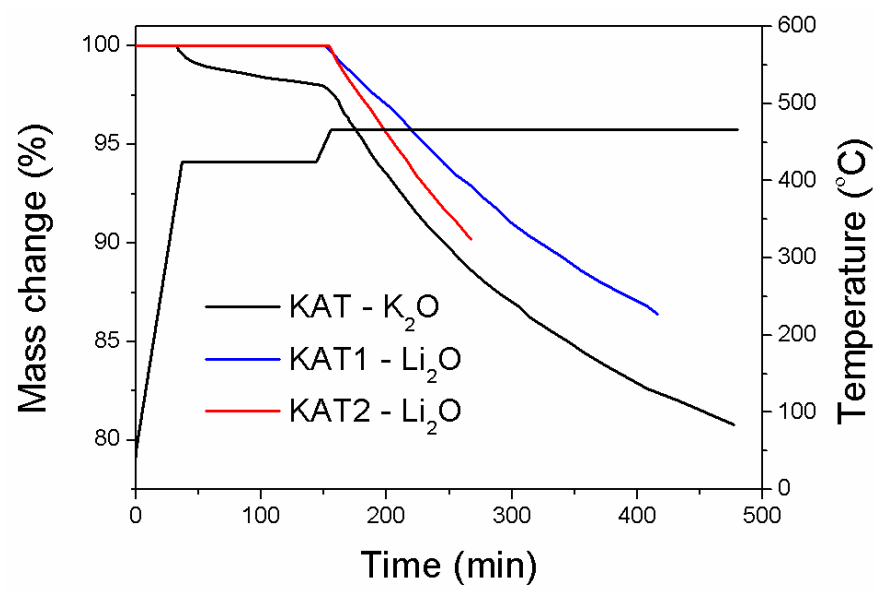

Figure 2. TG reduction curves for $\mathrm{KAT}-\mathrm{K}_{2} \mathrm{O}, \mathrm{KAT} 1-\mathrm{Li}_{2} \mathrm{O}$, and $\mathrm{KAT} 2-\mathrm{Li}_{2} \mathrm{O}$ catalysts.

Only the precursor of the catalyst promoted with potassium oxide $\left(\mathrm{KAT}-\mathrm{K}_{2} \mathrm{O}\right)$, in which the wustite phase was present, started being reduced at a temperature of $420{ }^{\circ} \mathrm{C}$. On the basis of literature [1], it was known that the $\mathrm{FeO}$ phase started being reduced at a temperature of $380{ }^{\circ} \mathrm{C}$. The catalyst precursor promoted with lithium oxide characterized with $\mathrm{R}=0.68\left(\mathrm{KAT} 1-\mathrm{Li}_{2} \mathrm{O}\right)$ had a similar molar ratio $\mathrm{Fe}^{2+} / \mathrm{Fe}^{3+}$ as the precursor promoted with potassium oxide. However, the reduction process of that precursor as well as the catalyst promoted with lithium oxide started at a higher temperature.

In the initial stage, the reductions of $\mathrm{KAT}-\mathrm{K}_{2} \mathrm{O}$ and $\mathrm{KAT} 2-\mathrm{Li}_{2} \mathrm{O}$ precursors were similar. The reduction of KAT1- $\mathrm{Li}_{2} \mathrm{O}$ ran slower (Figure 3).

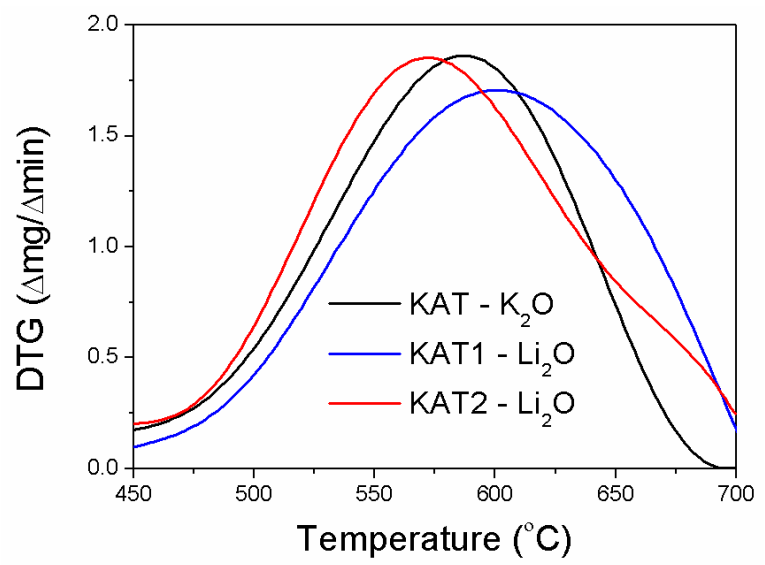

Figure 3. DTG curves calculated from the polythermal reduction of $\mathrm{KAT}-\mathrm{K}_{2} \mathrm{O}, \mathrm{KAT} 1-\mathrm{Li}_{2} \mathrm{O}$, and $\mathrm{KAT} 2-\mathrm{Li}_{2} \mathrm{O}$ catalyst precursors.

In the case of $\mathrm{KAT} 2-\mathrm{Li}_{2} \mathrm{O}$, for which only the magnetite phase was identified in the X-ray pattern, the highest reduction rate was observed at $571{ }^{\circ} \mathrm{C}$. For KAT- $\mathrm{K}_{2} \mathrm{O}$ and $\mathrm{KAT} 1-\mathrm{Li}_{2} \mathrm{O}$ catalyst precursors the highest reduction rate was observed at $587^{\circ} \mathrm{C}$ and $600^{\circ} \mathrm{C}$ respectively. The inflection at a temperature of about $680{ }^{\circ} \mathrm{C}$ was visible on the DTA curve made for $\mathrm{KAT} 2-\mathrm{Li}_{2} \mathrm{O}$. It may have pointed out the reduction of the harder reducible phase required higher temperature. It was confirmed by further results.

Results on the polythermal reduction of the industrial catalyst KAT- $\mathrm{K}_{2} \mathrm{O}$ precursor in an XRK 900 reaction chamber are presented in (Figure 4). Changes of peak intensities, given as peak areas (they are depicted by the Is symbols), of individual phases in dependence on temperature are presented. 


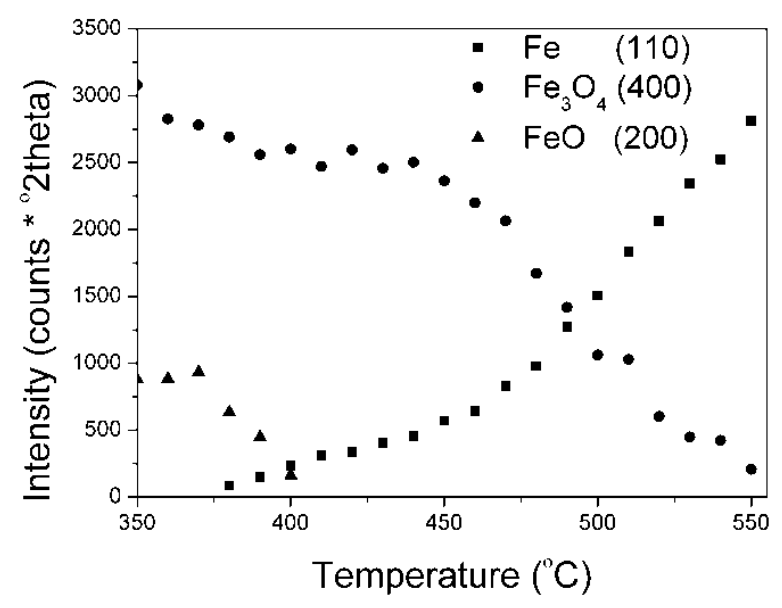

Figure 4. Dependence of peak intensities, expressed as a peak area (Is), of individual phases $\left(\mathrm{Fe}_{3} \mathrm{O}_{4}\right.$, $\mathrm{FeO}$, and $\mathrm{Fe}$ ) on the reduction temperature of the industrial catalyst precursor $\mathrm{KAT}-\mathrm{K}_{2} \mathrm{O}$. Heating rate- $2.5^{\circ} / \mathrm{min}$. For better view the peak intensity of Fe phase was divided by 5 .

Results on the polythermal reduction of the catalyst precursor promoted with potassium oxide were in a good accordance with literature data [1]. At first, the wustite phase reduction took place $\left(380-410{ }^{\circ} \mathrm{C}\right)$, then the magnetite phase $\left(440-550^{\circ} \mathrm{C}\right)$ was reduced.

The reduction of the industrial catalyst precursor KAT- $\mathrm{K}_{2} \mathrm{O}$ was examined in-situ under isothermal conditions at a temperature of $470{ }^{\circ} \mathrm{C}$ (Supplementary Materials Figures S1 and S2).

The dependence of peak intensity changes on reduction temperature of the catalyst precursors KAT1- $\mathrm{Li}_{2} \mathrm{O}$ and $\mathrm{KAT} 2-\mathrm{Li}_{2} \mathrm{O}$ are shown in (Figures 5 and 6).

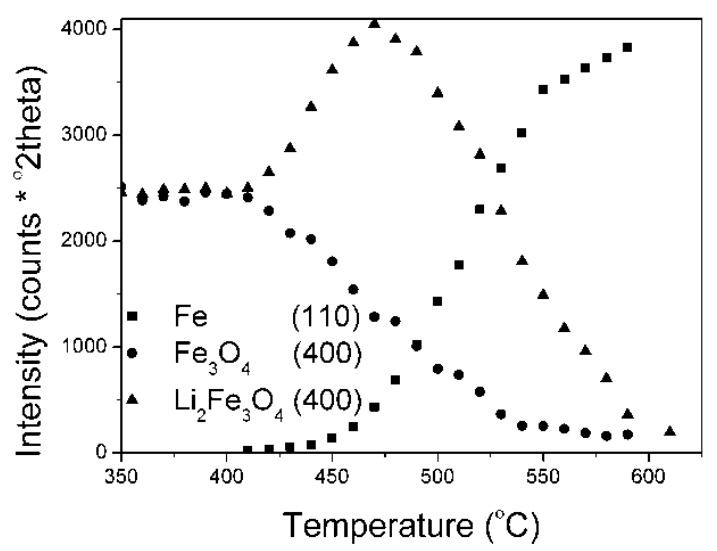

Figure 5. Dependence of peak intensities of $\mathrm{Fe}_{3} \mathrm{O}_{4}$, of the KAT1- $\mathrm{Li}_{2} \mathrm{O}$ catalyst precursor. $\mathrm{Li}_{2} \mathrm{Fe}_{3} \mathrm{O}_{4}$, and $\mathrm{Fe}$ on the reduction temperature of the $\mathrm{KAT} 1-\mathrm{Li}_{2} \mathrm{O}$ catalyst precursor. Heating rate $-2.5^{\circ} \mathrm{C} / \mathrm{min}$. For better view the peak intensity of Fe phase was divided by 4 .

In the initial stage (from a temperature of $410{ }^{\circ} \mathrm{C}$ ) the magnetite phase of the $\mathrm{KAT} 1-\mathrm{Li}_{2} \mathrm{O}$ was reduced (Figure 5). An increase in the area of $\mathrm{Li}_{2} \mathrm{Fe}_{3} \mathrm{O}_{4}$ phase peak was visible at the same time. In the $\mathrm{KAT} 2-\mathrm{Li}_{2} \mathrm{O}$, of $\mathrm{R}=0.54$, lithium was only in the form of a solid solution in magnetite. The reduction process was noticeable at temperatures close to $450{ }^{\circ} \mathrm{C}$ (Figure 6).

The reduction process of $\mathrm{Li}_{2} \mathrm{Fe}_{3} \mathrm{O}_{4}$ in the KAT1- $\mathrm{Li}_{2} \mathrm{O}$ catalyst did not run directly to iron in. On X-ray patterns in (Supplementary Materials, Figure S3), it may have been observed that the peak of the $\mathrm{Li}_{2} \mathrm{Fe}_{3} \mathrm{O}_{4}$ phase was asymmetric (it was broadened at lower scattering angles), what showed that a new phase was formed. It may have been supposed that the new phase was $\mathrm{Li}_{2} \mathrm{O} \cdot x \mathrm{FeO}$, where $\mathrm{x}>3$. During the reduction process, a precise analysis of intensities and shapes of peaks belonging to $\mathrm{Fe}_{3} \mathrm{O}_{4}$ and $\mathrm{Li}_{2} \mathrm{Fe}_{3} \mathrm{O}_{4}$ phases was carried out. The X-ray pattern, in the scattering angle range $2 \Theta$ from $41^{\circ}$ 
to $44^{\circ}$, taken in the reduction stage when the intensity of the $\mathrm{Li}_{2} \mathrm{Fe}_{3} \mathrm{O}_{4}$ peak was maximal, and the intensity of $\mathrm{Fe}_{3} \mathrm{O}_{4}$ peak decreased of $50 \%$, are presented in (Figure 7).

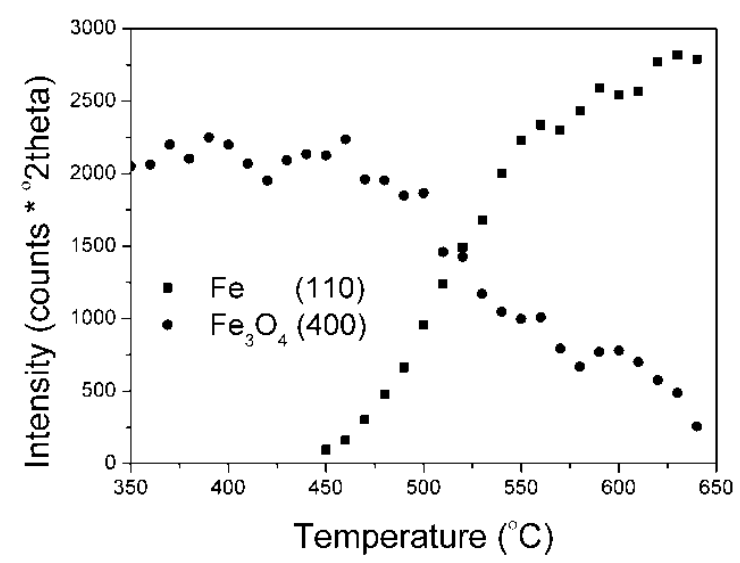

Figure 6. The dependence of peak intensities of $\mathrm{Fe}_{3} \mathrm{O}_{4}$ and $\mathrm{Fe}$ phases on the reduction temperature of the $\mathrm{KAT} 2-\mathrm{Li}_{2} \mathrm{O}$ catalyst precursor. Heating rate- $2.5^{\circ} \mathrm{C} / \mathrm{min}$. For better view the peak intensity of $\mathrm{Fe}$ phase was divided by 2 .

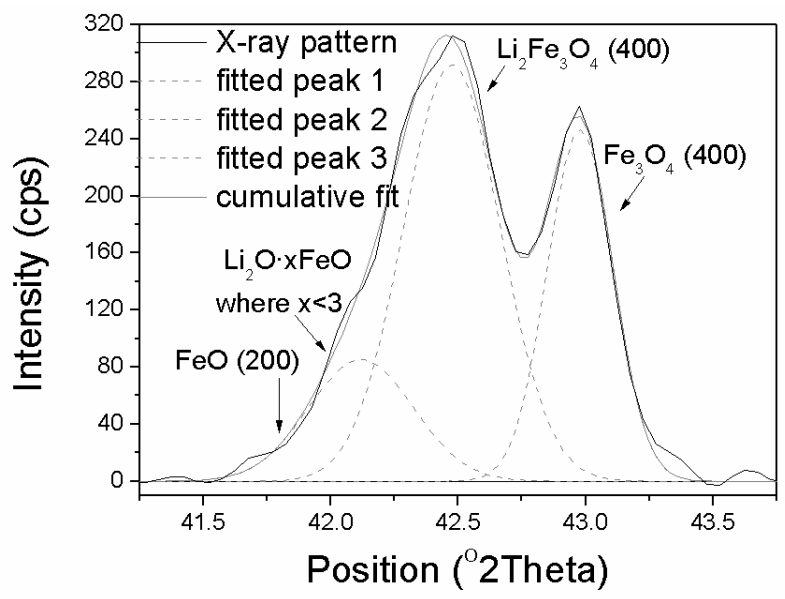

Figure 7. The deconvoluted X-ray pattern at the maximal intensity of the $\mathrm{Li}_{2} \mathrm{Fe}_{3} \mathrm{O}_{4}$ peak of the $\mathrm{KAT} 1-\mathrm{Li}_{2} \mathrm{O}$ catalyst precursor.

Deconvolution of that peak confirmed that during the reduction of the $\mathrm{Li}_{2} \mathrm{Fe}_{3} \mathrm{O}_{4}$ phase a new transient phase occurred. Much better fitting was found when an additional peak at the angle $2 \theta$ of $42.1^{\circ}$ was inserted (left of the phase $\mathrm{Li}_{2} \mathrm{Fe}_{3} \mathrm{O}_{4}$ phase, $2 \theta=42.45^{\circ}$ ). The peak could not be ascribed to the $\mathrm{FeO}$ phase because it would occur at the lower angle $2 \theta=41.80^{\circ}$ and at a temperature of $460{ }^{\circ} \mathrm{C}$ it would be reduced rapidly (Supplementary Materials Figure S1).

The analysis of the maximum position of the $\mathrm{Li}_{2} \mathrm{Fe}_{3} \mathrm{O}_{4}$ peak during the reduction process is shown in (Figure 8).

In the initial stage of the magnetite phase reduction, a new additional compound $\mathrm{Li}_{2} \mathrm{O} \cdot \mathrm{xFeO}$ was formed. It shifted the peak maximum of $\mathrm{Li}_{2} \mathrm{Fe}_{3} \mathrm{O}_{4}$ towards lower angles (the increase in lattice constant). After the reduction of the new phase $\mathrm{Li}_{2} \mathrm{O} \cdot x \mathrm{FeO}$, the maximum shifted towards higher angles (the decrease in lattice constant). Shifts towards higher angles were connected with non-stoichiometry of $\mathrm{Li}_{2} \mathrm{O} \cdot x \mathrm{FeO}$, where $\mathrm{x}<3$. During the reduction, $\mathrm{FeO}$ was reduced to $\mathrm{Fe}$. The presence of lithium caused that magnetite was not reduced directly to $\mathrm{Fe}$, but to $\mathrm{FeO}$ at a temperature of $460{ }^{\circ} \mathrm{C}$. That oxide combined with $\mathrm{Li}_{2} \mathrm{O}$ forming the additional phase $\mathrm{Li}_{2} \mathrm{O} \cdot x \mathrm{FeO}$. It is known from literature [36] that magnetite was reduced only at temperatures over $570{ }^{\circ} \mathrm{C}$ through wustite to iron. The authors' views on the direct reduction of magnetite to metallic iron are divided. Authors of the work [1], on the basis of "in situ" examinations carried out in a reaction chamber, made with the aid of 
XRD method, confirmed the presence of wustite after the reduction at a temperature of $413{ }^{\circ} \mathrm{C}$. Other authors on the ground of chemical analysis and Mössbauer investigations $[37,38]$ made the wustite formation impossible during the reduction of the magnetite precursor. Results of our research confirmed that magnetite was reduced to iron through the wustite phases. The same phenomenon was observed for $\mathrm{KAT}-\mathrm{Li}_{2} \mathrm{O}$ in which lithium formed a solid solution in magnetite. Regarding temperature shifts connected with a lattice constant extend, isothermal examinations gave more information (Supplementary Materials Figure S4).

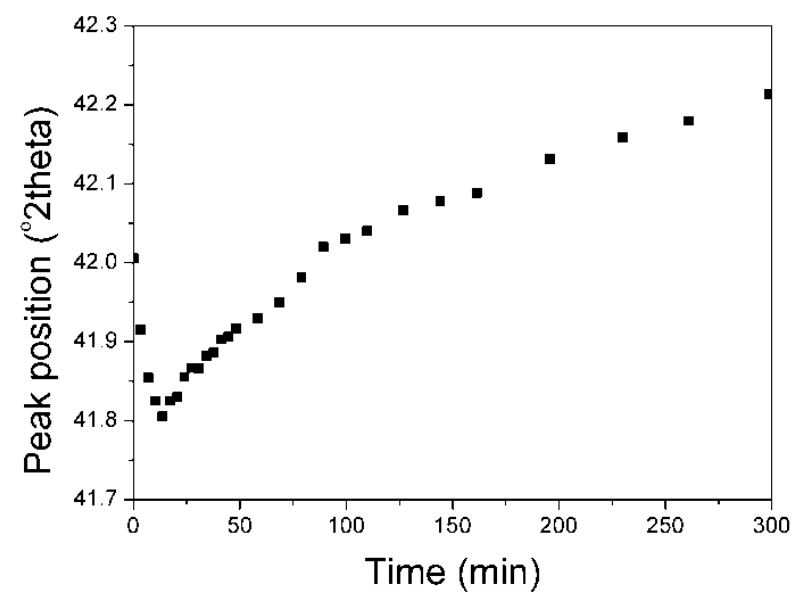

Figure 8. Changes in the maximum position of the $\mathrm{Li}_{2} \mathrm{O} \cdot x \mathrm{FeO}$ phase peak during the reduction of the KAT1- $\mathrm{Li}_{2} \mathrm{O}$ precursor.

The change of $\mathrm{Fe}_{3} \mathrm{O}_{4}$ peak position, during the isothermal reduction, in the dependence on time was presented in (Figure 9).

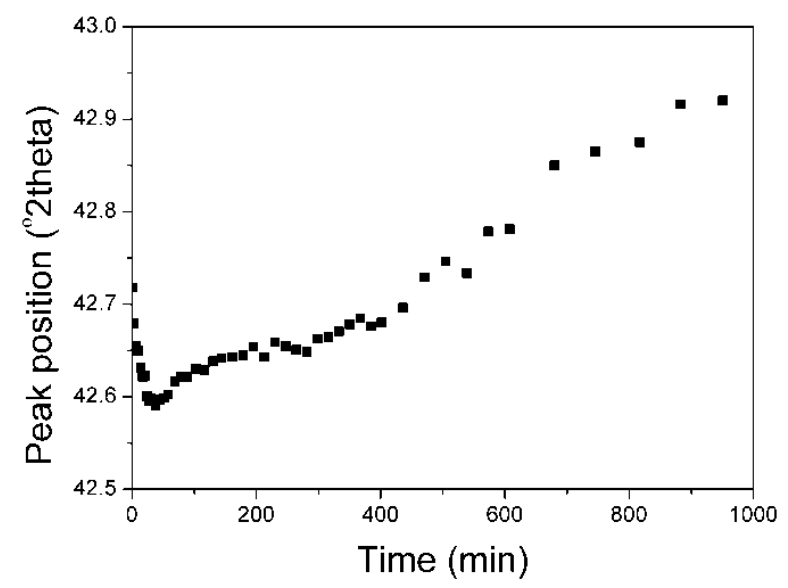

Figure 9. Changes in $\mathrm{Fe}_{3} \mathrm{O}_{4}$ phase peak maximum position during the precursor reduction of $\mathrm{KAT} 2-\mathrm{Li}_{2} \mathrm{O}$.

Similarly to the KAT1- $\mathrm{Li}_{2} \mathrm{O}$ catalyst, the shift of the peak maximum towards lower angles was observed what may have been attributed to a new phase $\mathrm{Li}_{2} \mathrm{O} \cdot \mathrm{xFeO}($ where $\mathrm{x}<3$ ) formation. After the maximum of asymmetry had been attained it started getting smaller causing the shift of total peak towards higher angles.

The average size of iron crystallites formed during the reduction processes of the examined catalysts was also compared (Figure 10). 


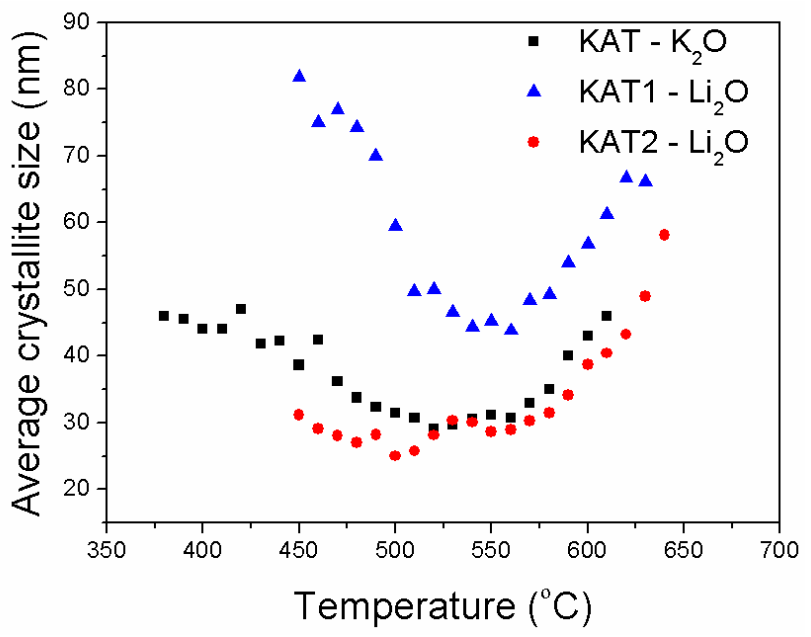

Figure 10. Changes in the average size of iron crystallites as a function of the reduction temperature.

Sizes of iron crystallites formed during the reduction of KAT- $\mathrm{K}_{2} \mathrm{O}$ and $\mathrm{KAT} 2-\mathrm{Li}_{2} \mathrm{O}$ catalysts were very similar for both catalysts. It was found that the industrial catalyst of the magnetite structure and promoted with potassium oxide was fully reduced at $500{ }^{\circ} \mathrm{C}$. The average size of iron crystallites was around $30 \mathrm{~nm}$. The further increase in reduction temperature caused the recrystallization process and increase in size of iron crystallites.

Catalysts promoted with lithium oxide reached the full reduction only at a temperature of $600{ }^{\circ} \mathrm{C}$. Under these conditions, the iron recrystallization process run; the average size of crystallites was in the range of $40 \mathrm{~nm}$ to $60 \mathrm{~nm}$.

The catalyst KAT1- $\mathrm{Li}_{2} \mathrm{O}$ containing the additional phase $\mathrm{Li}_{2} \mathrm{Fe}_{3} \mathrm{O}_{4}$ was reduced faster and formed crystallites of iron that recrystallized easily while temperature rose. Structural promoters calcium and aluminum oxides, protecting iron against sintering, were released during the magnetite phase reduction, and formed a three-dimensional (3-D) structure; it means they formed bridges between iron crystallites. Significantly bigger iron crystallites were observed for the catalyst $\mathrm{KAT1}-\mathrm{Li}_{2} \mathrm{O}$ than for the catalysts $\mathrm{KAT} 2-\mathrm{Li}_{2} \mathrm{O}$ that contained only magnetite.

Arrhenius curves for the tested catalyst reduced at a temperature of $500{ }^{\circ} \mathrm{C}$ and after reduction at $650^{\circ} \mathrm{C}$ are shown in Figure 11.

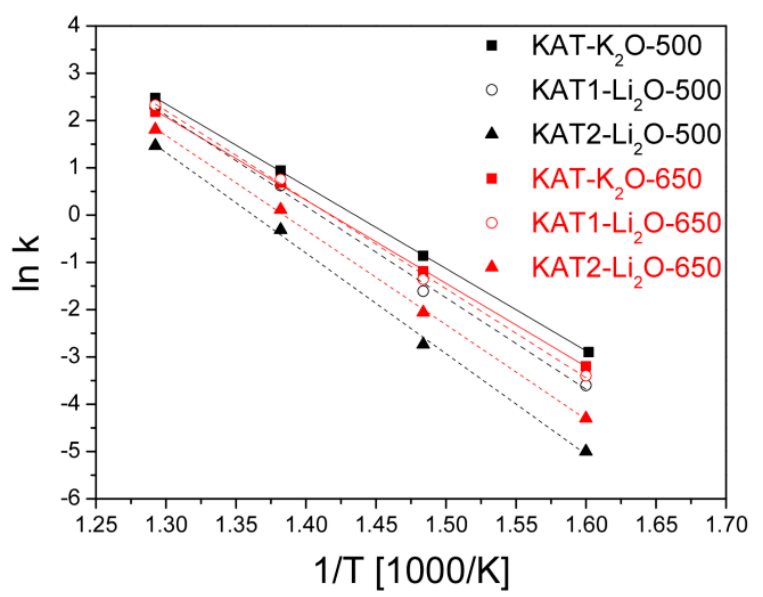

Figure 11. Arrhenius plots for the catalysts reduced at $500{ }^{\circ} \mathrm{C}$ and $650{ }^{\circ} \mathrm{C}$ temperatures.

Apparent activation energies were calculated from slopes of straights for catalysts reduced at various temperatures, Table 2. 
Table 2. Apparent activation energy for catalysts reduced at $500{ }^{\circ} \mathrm{C}$ and $650{ }^{\circ} \mathrm{C}$.

\begin{tabular}{ccc}
\hline & \multicolumn{2}{c}{$\mathrm{E}_{\mathbf{a}}[\mathbf{k J} / \mathbf{m o l}]$} \\
\cline { 2 - 3 } Catalyst Name & $\mathbf{5 0 0}{ }^{\circ} \mathbf{C}$ & $\mathbf{6 5 0}^{\circ} \mathbf{C}$ \\
\hline KAT- $\mathrm{K}_{2} \mathrm{O}$ & 144 & 149 \\
$\mathrm{KAT} 1-\mathrm{Li}_{2} \mathrm{O}$ & 161 & 156 \\
$\mathrm{KAT} 2-\mathrm{Li}_{2} \mathrm{O}$ & 176 & 166 \\
\hline
\end{tabular}

Catalysts promoted with lithium oxide and reduced at a temperature of $650{ }^{\circ} \mathrm{C}$ showed lower activity compared to the catalyst $\mathrm{KAT}-\mathrm{K}_{2} \mathrm{O}$ promoted with potassium oxide. However, properties of the catalyst promoted with lithium oxide after reduction at $650{ }^{\circ} \mathrm{C}$ were very interesting - their activity rose.

The completed reduction at that temperature caused releasing of lithium oxide onto the iron surface. It was found [35] from TPD- $\mathrm{H}_{2}$ tests that the amount of hydrogen sorption sites on the surface of catalysts promoted with lithium oxide and reduced at $6500^{\circ} \mathrm{C}$ were significantly increased in comparison with the reduction at $500{ }^{\circ} \mathrm{C}$ when the total surface area was taken into account. As a result of the increase in the catalyst reduction degree at $650{ }^{\circ} \mathrm{C}$, the catalyst absolute activity increased while lithium oxide concentration on the catalyst surface increased. However, the average size of crystallites was bigger at the same temperature as a result of the sintering, Figure 10.

\section{Materials and Methods}

Precursors of catalysts for the ammonia synthesis were obtained by a fusing method in a laboratory plant for fused catalysts, Scheme 1 [39]. Feeding mixtures for the melting of catalysts were made of magnetite ore and oxide of calcium, aluminum, and lithium hydroxide. Molar ratio $\mathrm{Fe}^{2+} / \mathrm{Fe}^{3+}$ was adjusted using a proper amount of reducer, added during the melting process. With this technique, catalysts with various $\mathrm{Fe}^{2+} / \mathrm{Fe}^{3+}$ ratios were prepared. Precursors of catalyst with a constant ratio of the mass of promoter oxides to mass of iron $\left(\mathrm{Al}_{2} \mathrm{O}_{3}-0.027, \mathrm{CaO}-0.015\right.$, and $\left.\mathrm{Li2}-0.011\right)$ were studied. These catalysts were signed as KAT1- $\mathrm{Li}_{2} \mathrm{O}$ and $\mathrm{KAT} 2-\mathrm{Li}_{2} \mathrm{O}$.

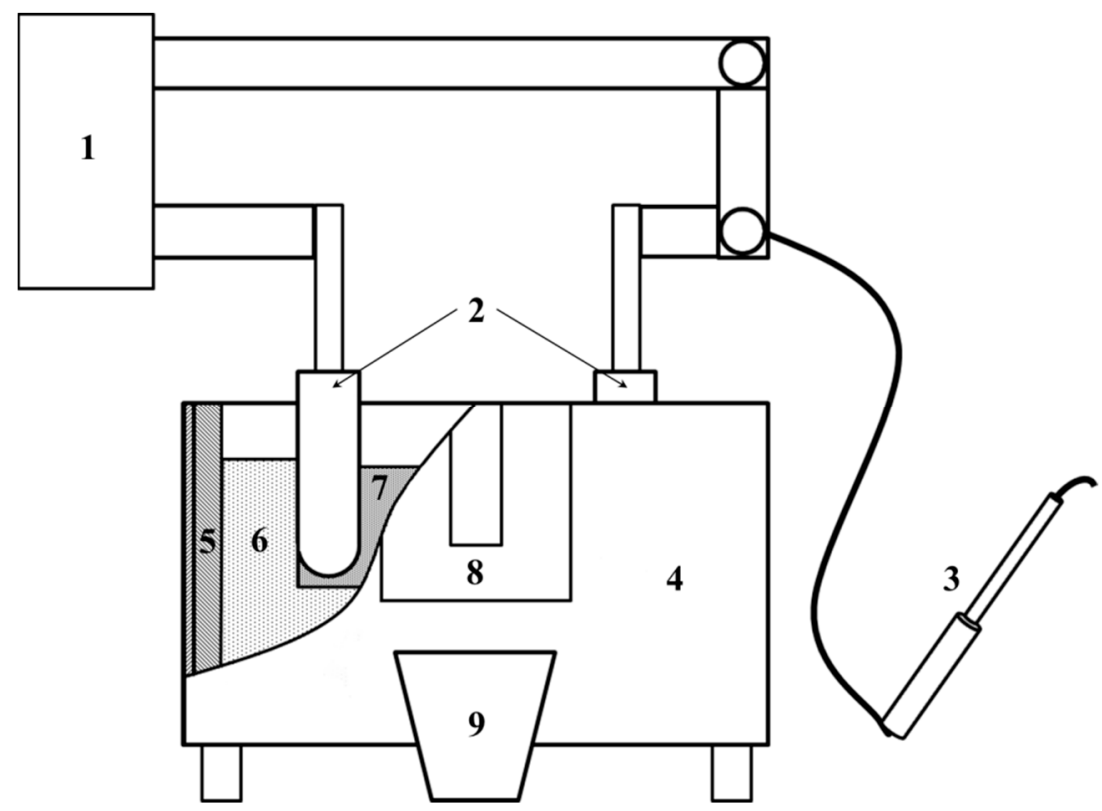

Scheme 1. Scheme of the laboratory plant for fused catalysts synthesis: (1) Multi-tap transformer with a control system, (2) Water-cooled fusing electrodes, (3) auxiliary electrode, (4) fuse reactor, (5) (6) insulation, (7) batch, (8) casting chamber, and (9) lava pouring box. 
Chemical compositions of catalyst precursors were determined with the aid of inductively coupled plasma atomic emission spectroscopy (ICP-AES) using the PerkinElmer Optima 5300 DV (Waltham, MA, USA) spectrometer.

The ratio $\mathrm{Fe}^{2+} / \mathrm{Fe}^{3+}$ was determined with the manganometric titration method and denoted with an $\mathrm{R}$ letter in the whole paper.

The reduction of catalyst precursors was studied in a differential reactor equipped with a thermogravimetric measurement, in a hydrogen atmosphere at a flow of $80 \mathrm{dm}^{3} \cdot \mathrm{h}^{-1} \cdot \mathrm{g}^{-1}$ under iso$\left(470{ }^{\circ} \mathrm{C}\right.$ ) and polythermal conditions during a heating from $350{ }^{\circ} \mathrm{C}$ to $750{ }^{\circ} \mathrm{C}$ at a rate of $3.5^{\circ} \mathrm{C} / \mathrm{min}$.

In situ studies of the reduction of the catalysts were carried out in reaction chamber XRK900 (Antor Paar, Blankenfelde-Mahlow, German), connected with X-ray diffraction apparatus Philips $X^{\prime}$ Pert PRO (Almelo, The Netherland) using $\mathrm{Cu}-\mathrm{K} \alpha$ radiation $(\lambda=1.54 \AA)$. The reduction was carried out in a hydrogen atmosphere at a flow of $60 \mathrm{dm}^{3} \cdot \mathrm{h}^{-1} \cdot \mathrm{g}^{-1}$ at a heating rate of $2.5^{\circ} \mathrm{C} / \mathrm{min}$. The same diffractometer was used to determine a phase composition of the examined catalysts. Taken X-ray patterns were analyzed with the X'Pert HighScore Plus software (version 2.2, PANalytical, Almelo, The Netherland) and compared with the ICDD database.

The catalytic activity was measured in a six-channel integral reactor at the pressure of $10 \mathrm{MPa}$. A detailed description of the method has been reported previously in this work [34]. Before activity tests, samples of the oxidized form of the catalysts were reduced polythermally in the temperature range of $350-500{ }^{\circ} \mathrm{C}$, at a pressure of $0.1 \mathrm{MPa}$, by means of a nitrogen-hydrogen mixture using space velocity of about $20,000 \mathrm{~h}^{-1}$. The final stage of reduction was executed at a pressure of $10 \mathrm{MPa}$ and at a temperature of $500{ }^{\circ} \mathrm{C}$. The activity studies were carried out under the same pressure in the temperature range of $350-500{ }^{\circ} \mathrm{C}$. The rate constant calculated from the Temkin-Pyzhew equation was accepted as a measure of the activity. Subsequently, the catalysts were reduced polythermally into $650{ }^{\circ} \mathrm{C}$, at a pressure of $0.1 \mathrm{MPa}$. When reduction was completed, the determination of the catalyst activities was performed again.

\section{Conclusions}

Lithium oxide was built into the magnetite structure during the melting process of the iron catalyst precursor and/or it formed the separate phase with iron(II) oxide. The form of lithium oxide binding depended on reduction-oxidation conditions during the fusing process. In the excess of $\mathrm{Fe}^{2+}$ ions of the additional phase, $\mathrm{Li}_{2} \mathrm{Fe}_{3} \mathrm{O}_{4}$ occurred. That phase was reduced at a lower temperature in comparison with the solid solution of lithium in iron.

Lithium oxide forming the solid solution in the magnetite accelerated the reduction process of the magnetite phase. It was observed that magnetite in the presence of lithium oxide was not reduced to iron directly, however, a new intermediate phase occurred, of which the reduction was much slower.

Fused catalysts promoted with lithium oxide showed lower activity in comparison with catalysts promoted with potassium oxide because the lithium promoted catalysts needed to be reduced at higher temperatures, which was the reason of the sintering of iron crystallites.

Supplementary Materials: The following are available online at http:/ /www.mdpi.com/2073-4344/8/11/494/s1, Figure S1. Demonstration X-ray patterns of the industrial catalyst precursor $\mathrm{KAT}-\mathrm{K}_{2} \mathrm{O}$ taken after various reduction times at a temperature of $470{ }^{\circ} \mathrm{C}$, Figure S2. Dependence of peak intensities of $\mathrm{Fe}_{3} \mathrm{O}_{4}, \mathrm{FeO}$, and Fe on the reduction time for the industrial catalyst precursor $\mathrm{KAT}-\mathrm{K}_{2} \mathrm{O}\left(\mathrm{T}=470{ }^{\circ} \mathrm{C}\right)$. For better view the peak intensity of Fe phase was divided by 4 , Figure S3. X-ray patterns taken after various times of KAT1- $\mathrm{Li}_{2} \mathrm{O}$ catalyst precursor reduction at a temperature of $520^{\circ} \mathrm{C}$, Figure S4. X-ray patterns of the KAT2- $\mathrm{Li}_{2} \mathrm{O}$ catalyst after various time of the reduction at $520^{\circ} \mathrm{C}$.

Funding: This research received no external funding.

Acknowledgments: This work was supported by the Polish National Research and Development Centre No. Tango2/340001/NCBR/2017.

Conflicts of Interest: The authors declare no conflicts of interest. 


\section{References}

1. Jennings, J. Catalytic Ammonia Synthesis: Fundamentals and Practice; Plenum Press: New York, NY, USA, 1991.

2. Nielsen, A. An Investigation on Promoted Iron Catalysts for the Synthesis of Ammonia; Jul. Gjellerups Forlag: Copenhagen, Denmark, 1968.

3. Somorjai, G.A.; Li, Y. Introduction to Surface Chemistry and Catalysis; Wiley: New York, NY, USA, 1994.

4. Ertl, G. Reactions at Solid Surfaces; Wiley: New York, NY, USA, 2009.

5. Liu, H. Ammonia Synthesis Catalysts: Innovation and Practice; World Scientific: Singapore, 2013.

6. Chianese, S.; Loipersböck, J.; Malits, M.; Rauch, R.; Hofbauer, H.; Molino, A.; Musmarra, D. Hydrogen from the high temperature water gas shift reaction with an industrial $\mathrm{Fe} / \mathrm{Cr}$ catalyst using biomass gasification tar rich synthesis gas. Fuel Process. Technol. 2015, 132, 39-48. [CrossRef]

7. Nam, H.; Wang, Z.; Shanmugam, S.R.; Adhikari, S.; Abdoulmoumine, N. Chemical looping dry reforming of benzene as a gasification tar model compound with Ni- and Fe-based oxygen carriers in a fluidized bed reactor. Int. J. Hydrogen Energy 2018, 43, 18790-18800. [CrossRef]

8. Lang, C.; Sécordel, X.; Kiennemann, A.; Courson, C. Water gas shift catalysts for hydrogen production from biomass steam gasification. Fuel Process. Technol. 2017, 156, 246-252. [CrossRef]

9. Maj, K.; Kocemba, I.; Lendzion-Bielun, Z.; Arabczyk, W. Effect of cobalt addition on the activity of nanocrystaline iron catalysts in craking of methane. Adsorpt. Sci. Technol. 2015, 6-8, 559-566. [CrossRef]

10. Lendzion-Bieluń, Z.; Arabczyk, W. Fused Fe-Co catalysts for hydrogen production by means of the ammonia decomposition reaction. Catal. Today 2012, 212, 215-219. [CrossRef]

11. Lendzion-Bieluń, Z.; Jędrzejewski, R.; Ekiert, E.; Arabczyk, W. Heterogenity of ingot of the fused iron catalyst for ammonia synthesis. Appl. Catal. A 2011, 400, 48-53. [CrossRef]

12. Lendzion-Bielun, Z. A comparison of the distribution of promoters in reduced and oxidized form of iron catalyst for ammonia synthesis. Pol. J. Chem. 2007, 81, 433-440.

13. Lendzion-Bieluń, Z.; Jędrzejewski, R. Determination of the content of promoters in magnetite and wustite phases in the fused iron catalyst. Pol. J. Chem. Technol. 2013, 15, 27-29. [CrossRef]

14. Czekajło, Ł.; Lendzion-Bieluń, Z. Wustite based iron-cobalt catalyst for ammonia synthesis. Catal. Today 2017, 286, 114-117. [CrossRef]

15. Ertl, G.; Lee, S.; Weiss, M. Adsorption of nitrogen on potassium promoted Fe (111) and (100) surfaces. Surf. Sci. 1982, 114, 527-545. [CrossRef]

16. Altenburg, K.; Bosch, H.; Van Ommen, J.; Gellings, P. The role of potassium in iron catalysts for ammonia synthesis. J. Catal. 1980, 66, 326-334. [CrossRef]

17. Strongin, D.; Somorjai, G. Alkali Adsorption on Metals and Semiconductors. J. Catal. 1988, 109, 51-60. [CrossRef]

18. Bare, S.R.; Strongin, D.R.; Somorjai, G.A. Ammonia synthesis over iron single-crystal catalysts: The effects of alumina and potassium. J. Phys. Chem. 1986, 90, 4726-4729. [CrossRef]

19. Romotowski, T. Catalysts in the nitrogen industry. Przem. Chem. 1968, 47, 717-723.

20. Arabczyk, W.; Jasińska, I. The current state of knowledge of iron catalysts used in ammonia synthesis. Przem. Chem. 2006, 85, 130-137.

21. Kowalczyk, Z.; Jodzis, S. Iron catalyst impregnated with potassium hydroxide for the synthesis of ammonia. Przem. Chem. 1987, 66, 179-280.

22. Dmitrienko, L.M. Osnovy predvidlenya kataliticheskovo deistvia, Trudy IV Miezhdunarodnovo Kongresa po Katalizu. Nauk 1970, 1, 328.

23. Mross, W. Alkali Doping in Heterogeneous Catalysis. Catal. Rev. Sci. Eng. 1983, 25, 591-637. [CrossRef]

24. Arabczyk, W.; Jasińska, I.; Jędrzejewski, R. Iron catalyst for ammonia synthesis doped with lithium oxide. Catal. Commun. 2009, 10, 1821-1823. [CrossRef]

25. Aleksicz, B.; Mitov, J.G.; Klisurski, D.G.; Pietranowicz, N.A.; Jovanovic, N.N.; Bogdanov, S.S. Comparative investigations of the effect of alkaline promoters on the activity of ammonia synthesis catalysts at atmospheric and elevated pressures. Glas. Hem. Drusz. 1984, 49, 477-483.

26. Bosch, H.; Van Ommen, J.; Gellings, P. On the role of alkali metals in ammonia synthesis. Appl. Catal. 1985, 18, 405-408. [CrossRef] 
27. Wang, P.; Zhang, F.; Gao, W.; Wu, G.; He, T.; Chen, P. Breaking scaling relations to achieve low-temperature ammonia synthesis through LiH-mediated nitrogen transfer and hydrogenation. Nat. Chem. 2017, 9, 64-70. [CrossRef] [PubMed]

28. Baranski, A.; Lagan, M.; Pattek, A.; Reizer, A. Catalyst for Ammonia Synthesis. React. Kinet. Catal. Lett. 1980, 15, 285-291. [CrossRef]

29. Ertl, G.; Prigge, D.; Schloegl, R.; Weiss, M. Surface Characterization of Ammonia Synthesis Catalysts. J. Catal. 1983, 79, 359-377. [CrossRef]

30. Klisurski, D.; Mitov, I. MÖssbauer studies of the reduction of $\alpha-\mathrm{F}_{2} \mathrm{O}_{3}$ containing alkali metal hydroxide. J. Phys. Colloques 1979, 40, 353-354. [CrossRef]

31. Jensen, E.J.; Topsoe, H.; Soerensen, O.; Krag, F.; Candia, R.; Clausen, B.S.; Moerup, S. SEM studies of ammonia synthesis catalysts. Scand. J. Metall. 1977, 6, 6-8.

32. Zheng, Y.F.; Liu, H.Z.; Li, X.N. In situ X-ray diffraction study of reduction processes of $\mathrm{Fe}_{3} \mathrm{O}_{4}$ and $\mathrm{Fe}_{1-\mathrm{x}} \mathrm{O}$ based ammonia-synthesis catalysts. J. Solid State Chem. 2009, 182, 2385-2391. [CrossRef]

33. Lendzion-Bielun, Z.; Arabczyk, W. Method for determination of the chemical composition of phases of the iron catalyst precursor for ammonia synthesis. Appl. Catal. A Gen. 2001, 207, 37-41. [CrossRef]

34. Lendzion-Bieluń, Z.; Arabczyk, W.; Figurski, M. The effect of the iron oxidation state degree on distribution of promotors in the fused catalyst precursors and their activity in the ammonia synthesis reaction. Appl. Catal. A Gen. 2002, 227, 255-263. [CrossRef]

35. Jedrzejewski, R.; Lendzion-Bielun, Z.; Arabczyk, W. The activity of fused-iron catalyst doped with lithium oxide for ammonia synthesis. Pol. J. Chem. Technol. 2016, 18, 78-83. [CrossRef]

36. Aika, K.A. Nielsen in Ammonia: Catalysis and Manufacture; Springer: Berlin, Germany, 1995.

37. Mosesman, M.A. In situ X-Ray diffraction studies of heterogeneous reactions. J. Am. Chem. Soc. 1951, 73, 5635-5639. [CrossRef]

38. Pattek-Janczyk, A.; Hrynkiewicz, A.Z.; Kraczka, J.; Kulgawczuk, D. Studies on the reduction of an iron catalyst for ammonia synthesis: II. Mo“ssbauer studies on the reduction of an iron ammonia synthesis catalyst at different temperatures. Appl. Catal. 1983, 6, 35-40. [CrossRef]

39. Arabczyk, W.; Ziebro, J.; Kałucki, K.; Świerkowski, R.; Jakrzewska, M. Instalacja laboratoryjna do ciagłego wytopu katalizatorów żelazowych. Chemik 1996, 1, 22. 